\title{
Hansenula populi, a New Homothallic Species of Yeast from Exudates of Cottonwood Trees
}

\author{
H. J. PHAFF, ${ }^{*}$ YUZO YAMADA, $†$ JOANNE TREDICK, AND MARY MIRANDA \\ Department of Food Science and Technology, University of California, Davis, California 95616
}

The evolutionary affinities among several morphologically and physiologically similar species of the ascogenous yeast genus Hansenula were studied by a technique which involved genome comparisons in combination with nuclear deoxyribonucleic acid base composition determinations. The results revealed a new member of the genus Hansenula that was recovered five times in 1968 from slime exudates of Populus trichocarpa (cottonwood trees) in British Columbia and Alaska. This new species is named Hansenula populi because of its specific habitat in exudates of cottonwood trees. $H$. populi is homothallic and occurs naturally in the haploid state. Conjugation between vegetative cells precedes sporulation, and up to four hat-shaped spores are produced in zygotes. The spores are liberated from the asci soon after formation. $H$. populi resembles Hansenula nonfermentans and Hansenula dryadoides but differs from these species in habitat, guanine-plus-cytosine content of the nuclear deoxyribonucleic acid, maximum growth temperature, and ability to assimilate several carbon compounds. The type strain of $H$. populi is UCD-FS\&T $68-628 \mathrm{C}(=$ CBS $8094=$ ATCC 48773).

In 1968 Phaff et al. (8) isolated five strains of yeast from exudates of cottonwood trees (Populus trichocarpa Torrey and Gray) growing in five widely separated locations in British Columbia and Alaska. These strains were identified as Hansenula nonfermentans Wickerham by using the key provided by Wickerham (16). All five strains had similar properties. However, these properties differed from those of the type strain of $\boldsymbol{H}$. nonfermentans in the following respects: assimilation of trehalose negative or very weak, assimilation of L-rhamnose positive, assimilation of D-ribose and ribitol negative, assimilation of lactic acid and glucono- $\delta$-lactone positive, and growth at $37^{\circ} \mathrm{C}$ negative. $H$. nonfermentans was represented by only a single strain, which Wickerham isolated from the water of a mountain stream in Wyoming (16). The guanine-pluscytosine $(\mathrm{G}+\mathrm{C})$ contents of the nuclear deoxyribonucleic acids (DNAs) of two of our strains were close to the value reported by Nakase and Komagata (7) for the type strain of $\boldsymbol{H}$. nonfermentans, approximately $45 \mathrm{~mol} \% \mathrm{G}+\mathrm{C}$. Hansenula dryadoides, a more recently described species (11), was also included in our study, because it has a number of phenotypic properties in common with the yeasts isolated from cottonwood exudates. In this study we conducted DNA-DNA complementarity experiments to

\footnotetext{
† Present address: Laboratory of Applied Microbiology, Department of Agricultural Chemistry, Shizuoka University,
} Shizuoka 422, Japan. determine whether the five strains obtained from Populus exudates represent a new species of Hansenula. Because there was little complementarity between the DNA of $H$. nonfermentans and the DNAs of the strains isolated from cottonwood trees, we regard these strains as belonging to a new species of Hansenula, for which we propose the name Hansenula populi (pop'u.li. L. n. populus generic name of cottonwood; L. gen. n. populi of cottonwood) because its habitat is the exudate of cottonwood trees. A description of this new species is given below.

\section{MATERIALS AND METHODS}

Samples of slime fluxes were collected during June and July of 1968 in various locations of Alaska, the Yukon Territory, British Columbia, Washington, Oregon, and California (8). The precise locations of the samples from Populus which contained the new species of Hansenula are given in Table 1.

The samples were collected in new plastic vials or bags. Usually within 6 to $18 \mathrm{~h}$ after collection, a loopful of the slimy exudate was streaked directly onto 5\% malt agar acidified to $\mathrm{pH} 3.7$ with a precalculated amount of $1 \mathrm{~N} \mathrm{HCl}$. The plates were stored at ambient temperatures (ca. 15 to $25^{\circ} \mathrm{C}$ ) until colonies appeared. Despite the low $\mathrm{pH}$, varying numbers of bacterial colonies usually appeared together with colonies of yeasts. After 3 to 6 days, the plates were inspected with a dissecting microscope, and for identification purposes one yeast colony of each morphological type was brought into pure culture by two successive platings on malt agar. For further details concerning the collecting areas, see Table 1 and the study of Phaff et al. (8). 
TABLE 1. Strains used

\begin{tabular}{|c|c|c|}
\hline Strain $^{a}$ & Source & $\begin{array}{c}\mathrm{G}+\mathrm{C} \text { content of } \\
\text { nuclear DNA } \\
(\text { mol } \%)\end{array}$ \\
\hline H. populi UCD-FS\&T $68-628 \mathrm{C}^{\mathrm{T}}$ & $\begin{array}{l}\text { Exudate of } P \text {. trichocarpa, Alcan Highway } \\
55 \text { miles (ca. } 90 \mathrm{~km} \text { ) northwest of Dawson } \\
\text { Creek, British Columbia, } \\
\text { Canada }\end{array}$ & $44.2 \pm 0.35^{b}$ \\
\hline H. populi UCD-FS\&T 68-809C & $\begin{array}{l}\text { Exudate of } P \text {. trichocarpa, Alcan Highway } \\
2 \text { miles (ca. } 3.2 \mathrm{~km} \text { ) south of Fort Nelson, } \\
\text { Canada }\end{array}$ & $44.0 \pm 0.27$ \\
\hline H. populi UCD-FS\&T 68-676B & $\begin{array}{l}\text { Exudate of } P \text {. trichocarpa, Delta Junction, } \\
\quad \text { Alaska }\end{array}$ & $43.9 \pm 0.12$ \\
\hline H. populi UCD-FS\&T 68-644A & $\begin{array}{l}\text { Exudate of } P \text {. trichocarpa, Kenai } \\
\text { Peninsula, Alaska }\end{array}$ & $43.9 \pm 0.06$ \\
\hline H. populi UCD-FS\&T $68-603$ & $\begin{array}{l}\text { Exudate of } P \text { trichocarpa, Prince Rupert, } \\
\text { British Columbia, Canada }\end{array}$ & $43.8 \pm 0.40$ \\
\hline H. nonfermentans UCD-FS\&T $72-15^{\mathrm{T}}$ & Stream water, Wyoming & $45.3 \pm 0.16$ \\
\hline H. dryadoides UCD-FS\&T $80-296^{\mathrm{T}}$ & Insect tunnels in Ficus spp., South Africa & $31.0 \pm 0.09$ \\
\hline Saccharomyces cerevisiae UCD-FS\&T C-146 & Industrial champagne yeast & $39.5 \pm 0.19$ \\
\hline
\end{tabular}

" UCD-FS\&T, Collection of the Department of Food Science and Technology, University of California, Davis.

${ }^{b}$ Calculated from the average of at least three buoyant density determinations. Mean \pm standard deviation.

Identification of the isolates involved characters determined by standard methods currently used in yeast taxonomy (14). DNA extraction and purification were done by a combination of the procedures of Marmur (6) and Bernardi et al. (1), as described by Price et al. (9). The $\mathrm{G}+\mathrm{C}$ contents of the DNAs were calculated from buoyant density values in cesium chloride $(10,13)$ and were based on three separate determinations. The DNA of strain 2039 of Micrococcus luteus (synonym, "Micrococcus lysodeikticus" [not on the Approved Lists of Bacterial Names \{12\}]), which was obtained from the International Collection of Phytopathogenic Bacteria, Department of Bacteriology, University of California, Davis, was used as a reference (buoyant density, $1.7311 \mathrm{~g} / \mathrm{ml}$ ). The buoyant density of the " $M$. lysodeikticus" DNA was determined from a comparison with plasmid-free Escherichia coli $\mathrm{K}-12$ DNA, whose buoyant density was taken to be $1.7100 \mathrm{~g} / \mathrm{ml}$.

DNA reannealing reactions. For the reassociation experiments, purified DNA was concentrated by electrophoresis in an ISCO concentrator and subsequently adjusted to a concentration of $700 \mu \mathrm{g} / \mathrm{ml}$ before shearing. Reference DNA that was to be labeled with ${ }^{125} \mathrm{I}$ was further purified by ultracentrifugation with a Beckman model L ultracentrifuge to eliminate residual protein and ribonucleic acid before iodination. Peak fractions, as determined by absorbance at $260 \mathrm{~nm}$, were pooled and dialyzed against $0.113 \mathrm{M}$ ammonium acetate-0.053 M acetic acid buffer ( $\mathrm{pH} 5$ ) for $48 \mathrm{~h}$. Labeling with ${ }^{125} \mathrm{I}$ was done after the DNA solution was denatured in a glycol bath at $110^{\circ} \mathrm{C}$ by the method of Commerford (5), using approximately $200 \mu \mathrm{Ci}$ of ${ }^{125}$ I per $200 \mu \mathrm{g}$ of DNA. After subsequent shearing and removal of rapidly renaturing sequences (9), the activity of the labeled DNA was approximately $5 \times 10^{5}$ $\mathrm{cpm} / \mu \mathrm{g}$ of DNA.

Unlabeled DNA was sheared to an average molecular weight of approximately 300,000 by two passages through a miniature French press at $13,500 \mathrm{lb} / \mathrm{in}^{2}$.
Reference DNA (concentration, approximately 150 $\mu \mathrm{g} / \mathrm{ml}$ ) was sheared after iodination by the same method. After shearing, all DNAs were filtered through membrane filters (pore size, 0.45 or $1.2 \mu \mathrm{m}$; Metricel) to remove debris. Rapidly renaturing sequences were removed from the labeled DNA by the method of Price et al. (9).

The final concentrations of unlabeled and labeled DNAs were determined by the diphenylamine test (4). Subsequently, unlabeled DNA was diluted to a concentration of $500 \mu \mathrm{g} / \mathrm{ml}$, and labeled DNA was diluted to a concentration of $2 \mu \mathrm{g} / \mathrm{ml}$ for renaturation experiments.

The renaturation kinetics of the reference DNA was determined by a $\mathrm{C}_{\mathrm{o}} \mathrm{t}$ analysis (3). Reannealing reactions were done by using the protocol of Price et al. (9). Separation of single- and double-stranded DNAs was performed by the hydroxylapatite batch method (2), as modified by Price et al. (9). The resulting samples were transferred to counting tubes and counted with a Nuclear Chicago model 1185 gamma ray counter ( $90 \%$ efficiency). Calculations of sequence complementarity were performed by the method of Price et al. (9).

\section{RESULTS}

The nuclear DNA base compositions of the organisms studied are shown in Table 1 . We included $H$. dryadoides (11) in this study because this species has a significant number of phenotypic properties in common with the strains isolated from cottonwood trees. It is clear that of the two Hansenula species that have a significant number of phenotypic traits in common with $H$. populi, $H$. dryadoides obviously shows little relationship to $H$. populi. Thus far, in our laboratory, yeasts with base compositions differing by more than about $1.5 \mathrm{~mol} \%$ 
$\mathrm{G}+\mathrm{C}$ (as determined by the buoyant density equilibrium centrifugation technique) have not been found to be closely related. On the other hand, $H$. nonfermentans could be conspecific with $H$. populi.

Strain UCD-FS\&T $68-628 C^{\mathrm{T}}$ (type strain) of $H$. populi was chosen as the reference organism for DNA base sequence comparisons. The renaturation kinetics of homologous reference DNA from strain UCD-FS\&T $68-628 \mathrm{C}^{\mathrm{T}}$ were followed to $a C_{0} t$ value of $100 \mathrm{~mol} \cdot \mathrm{s} /$ liter $\left(\mathrm{C}_{\mathrm{o}} \mathrm{t}\right.$ is the initial nucleotide concentration [in moles per liter] multiplied by the time [in seconds] [3, 9]). At this stage renaturation was $67.5 \%$ complete. A modified Wetmur-Davidson plot (15) of the early data points of the $\mathrm{C}_{\mathrm{o}} \mathrm{t}$ curve showed that only $2.3 \%$ of the rapidly renaturing sequences remained in the radiolabeled preparation.

Table 2 shows the results of heterologous reannealing reactions when DNA from the type strain of $\boldsymbol{H}$. populi was used as the reference DNA. Three strains of $H$. populi shared more than $90 \%$ sequence complementarity with the $H$. populi reference strain. The fourth strain, strain UCD-FS\&T $68-603$, shared only $77 \%$ of its base sequences with the reference strain. Our results also clearly show that neither $H$. nonfermentans nor $H$. dryadoides had significant DNA sequence similarity to $H$. populi, thus precluding conspecificity.

H. populi strain UCD-FS\&T $68-603$ seemed to have undergone significant divergence from the other four strains studied. To determine whether this divergence was real or due to experimental imperfection, a reverse experiment was done, in which strain UCD-FS\&T 68-603 was labeled and used as a reference for the other strains. $H$. dryadoides was used as a negative control. Table 3 demonstrates that the other four strains of
$H$. populi all showed approximately corresponding lower degrees of homology with the reference strain. Although the results of reciprocal labeling experiments suggested that there may be a slight difference in genome size between strain UCD-FS\&T 68-603 and the other four strains of $H$. populi, the main difference appears to be a change in base sequences and a resulting genetic divergence.

The DNA reannealing experiments described above were the basis for regarding $H$. populi as a new species, and a description of this species is given below.

Latin diagnosis of Hansenula populi sp. nov. In extracto malti post dies 3 cellulae subovoideae aut rotundae, $2.0-5.0 \times 2.5-5.6 \mu \mathrm{m}$, singulae, binae, aut in catenis brevis; sedimentum et annulus tenuis formantur. Post dies 21 sedimentum formatur et annulus tenuis. Pellicula non formatur.

Cultura in agaro malti post 1 mensem $\left(20^{\circ} \mathrm{C}\right)$ cremea, mollis, nitida, glabra, demissa convexa aut plana; margo lobata aut glabra.

In agaro farinae Zea mays post dies 14 pseudomycelium vel mycelium verum nullum.

Species homothallica, haploideae. Orientur asci ex conjugatione inter cellulas haploideae. Pileiformae ascosporae formantur ad quattuor in quoque asco; asci rumpunter post 4-6 dies.

Fermentatio glucosi nullum.

Glucosum, cellobiosum, D-xylosum, L-rhamnosum, ethanolum, glycerolum, D-mannitolum, D-glucitolum, salicinum, glucono-delta-lactonum, acidum gluconicum, acidum lacticum, et acidum succinicum assimilantur, at non D-galactosum, L-sorbosum, maltosum, saccharosum, trehalosum, lactosum, melibiosum, raffinosum, melezitosum, inulinum, amylum solubile, L-arabinosum, D-arabinosum, D-ribosum, i-erythrito-

TABLE 2. Reannealing between labeled DNA from $H$. populi UCD-FS\&T 68-628C ${ }^{\mathrm{T}}$ and DNAs from seven strains of yeast and calf thymus ${ }^{a}$

\begin{tabular}{lccc}
\hline \multicolumn{1}{c}{ Organism or tissue } & $\begin{array}{c}\text { Actual } \\
\text { binding }(\%)^{b}\end{array}$ & $\begin{array}{c}\text { Corrected } \\
\text { actual } \\
\text { binding }(\%)^{c}\end{array}$ & $\begin{array}{c}\text { Relative } \\
\text { binding }(\%)^{c}\end{array}$ \\
\hline H. populi UCD-FS\&T 68-628C & $67.5 \pm 0.03^{d}$ & 66.4 & 100.0 \\
H. populi UCD-FS\&T 68-809C & $63.6 \pm 0.6$ & 62.4 & 94.0 \\
H. populi UCD-FS\&T 68-676B & $62.3 \pm 0.7$ & 61.1 & 91.9 \\
H. populi UCD-FS\&T 68-644A & $63.6 \pm 0.8$ & 62.4 & 94.0 \\
H. populi UCD-FS\&T 68-603 & $52.6 \pm 0.5$ & 51.0 & 76.8 \\
H. nonfermentans UCD-FS\&T 72-15 & $5.6 \pm 1.6$ & 2.5 & 3.8 \\
H. dryadoides UCD-FS\&T 80-296 & $4.7 \pm 0.4$ & 1.6 & 2.4 \\
Saccharomyces cerevisiae UCD-FS\&T C-146 & $5.6 \pm 0.4$ & 2.5 & 3.7 \\
Calf thymus & $4.1 \pm 0.4$ & 1.0 & 1.4 \\
\hline
\end{tabular}

a ${ }^{125}$ I-labeled DNA $(0.2 \mu \mathrm{g})$ and unlabeled DNA $(200 \mu \mathrm{g})$ were incubated in $0.5 \mathrm{ml}$ of $280 \mathrm{mM}$ phosphate buffer at $65.1^{\circ} \mathrm{C}$.

${ }^{b}$ Average of three samples, corrected for zero-time binding.

c Corrected for self-renaturation $(3.3 \pm 0.7 \%)(9)$.

${ }^{d}$ Mean \pm standard deviation. 
TABLE 3. Reannealing between labeled DNA from $H$. populi UCD-FS\&T 68-603 and DNAs from five strains of yeast and calf thymus ${ }^{a}$

\begin{tabular}{lccc}
\hline \multicolumn{1}{c}{ Organism or tissue } & $\begin{array}{c}\text { Actual } \\
\text { binding }(\%)^{b}\end{array}$ & $\begin{array}{c}\text { Corrected } \\
\text { actual } \\
\text { binding }(\%)^{c}\end{array}$ & $\begin{array}{c}\text { Relative } \\
\text { binding } \\
(\%)^{c}\end{array}$ \\
\hline H. populi UCD-FS\&T 68-603 & $58.9 \pm 0.5^{d}$ & 56.5 & 100 \\
H. populi UCD-FS\&T 68-628C & $39.2 \pm 2.0$ & 35.7 & 63.1 \\
H. populi UCD-FS\&T 68-809C & $42.4 \pm 0.7$ & 39.0 & 69.0 \\
H. populi UCD-FS\&T 68-676B & $41.7 \pm 0.3$ & 38.2 & 67.7 \\
H. populi UCD-FS\&T 68-644A & $42.1 \pm 0.9$ & 38.7 & 68.4 \\
H. dryadoides UCD-FS\&T 80-296 & $9.8 \pm 1.2$ & 4.5 & 8.0 \\
Calf thymus & $10.2 \pm 0.9$ & 4.9 & 8.7 \\
\hline
\end{tabular}

a ${ }^{125}$ I-labeled DNA $(0.2 \mu \mathrm{g})$ and unlabeled DNA $(200 \mu \mathrm{g})$ were incubated in $0.5 \mathrm{ml}$ of $280 \mathrm{mM}$ phosphate buffer at $64.3^{\circ} \mathrm{C}$.

${ }^{b}$ Average of three samples, corrected for zero-time binding.

${ }^{c}$ Corrected for self-renaturation $(5.9 \pm 1.4 \%)(9)$.

${ }^{d}$ Mean \pm standard deviation.

lum, ribitolum, galactitolum, $\alpha$-methyl-D-glucosidum, 2- et 5-ketogluconatum, acidum citricum, i-inositolum, methanolum, glucosaminum, nec hexadecanum.

Kalium nitricum, natrium nitrosum, ethyl aminum, et lysinum assimilantur.

Ad crescentium vitaminae externae necessariae sunt.

Crescere potest in $30^{\circ} \mathrm{C}$; nullum incrementum calore $33^{\circ} \mathrm{C}$.

Crescere potest in $1 \mu \mathrm{g}$ cyclohexamidum $/ \mathrm{ml}$; nullum incrementum in $10 \mu \mathrm{g}$ cyclohexami$\mathrm{dum} / \mathrm{ml}$.

$\mathrm{G}+\mathrm{C}$ acidi deoxyribonucleati, 43.8-44.2 mol\% (quinque stirpes) (Table 1).

Habitatio in exudati Populi trichocarpi.

Typus: stirps UCD-FS\&T 68-628C (= CBS 8094) ex exudato $P$. trichocarpi Canadensis isolata est.

In collectione zymotica Centraalbureau voor Schimmelcultures, Delphi Batavorum, sub no. 8094 deposita est.

Description of $H$. populi: growth in malt extract. After 3 days at $24^{\circ} \mathrm{C}$, the cells are short ovoid, sometimes spheroid, and measure 2.0 to 5.0 by 2.5 to $5.6 \mu \mathrm{m}$. They occur usually singly or in pairs, but sometimes in small clusters or short chains. A thin ring and a small amount of sediment are present, but no pellicle is formed. After 3 weeks a moderate amount of sediment is present, the ring is very thin or absent, and a film is lacking.

Growth on malt agar. After 1 month streak cultures are cream colored, smooth, shiny, soft, and low convex to flat in cross-section; the border is entire to finely lobed.

Dalmau plate culture on corn meal agar. After 12 days a pseudomycelium is absent or very rudimentary under aerobic conditions. Under a cover glass spotty clusters of undifferentiated cells growing into the agar are occasionally observed.
Formation of ascospores. Vegetative cells are mostly haploid and homothallic. Some diploid cells may occur. Conjugation takes place between two haploid cells of approximately equal size, and normally four derby hat-shaped spores develop in one of the cells, forming a dumbbellshaped ascus. Occasionally spores are formed in diploid cells. Asci lyse early, releasing the spores in groups of two, three, or four (Fig. 1). Good sporulation was obtained on malt agar after 2 to 4 days.

Other characteristics.

Glucose is not fermented.

The following carbon compounds are assimilated: D-glucose, cellobiose, D-xylose, L-rhamnose, ethanol, glycerol, D-mannitol, D-glucitol, salicin, glucono- $\delta$-lactone, gluconic acid, lactic acid, and succinic acid. D-Galactose, L-sorbose, maltose, sucrose, trehalose, lactose, melibiose, raffinose, melezitose, inulin, soluble starch, Larabinose, D-arabinose, D-ribose, i-erythritol, ribitol, galactitol, methyl- $\alpha$-D-glucoside, 2-ketogluconate, 5-ketogluconate, citrate, i-inositol, methanol, glucosamine, and hexadecane are not assimilated.

The following nitrogen compounds are assimilated: potassium nitrate, sodium nitrite, ethyl amine, and lysine.

Vitamin requirements: biotin and pyridoxine are required for growth; two strains (including the type strain) are stimulated by thiamine, whereas the other strains require thiamine.

Growth on $50 \%(\mathrm{wt} / \mathrm{wt})$ glucose-yeast extract agar: absent.

Growth on 10 and $7.5 \%(\mathrm{wt} / \mathrm{vol})$ sodium chloride-glucose-yeast extract agars: absent. Growth on $5 \% \mathrm{NaCl}$ agar: positive (latent).

Maximum temperature for growth: $30^{\circ} \mathrm{C}$.

Acid formation on chalk agar: positive (weak). Synthesis of starchlike compounds: negative. Gelatin liquefaction: negative.

Casein hydrolysis: negative. 

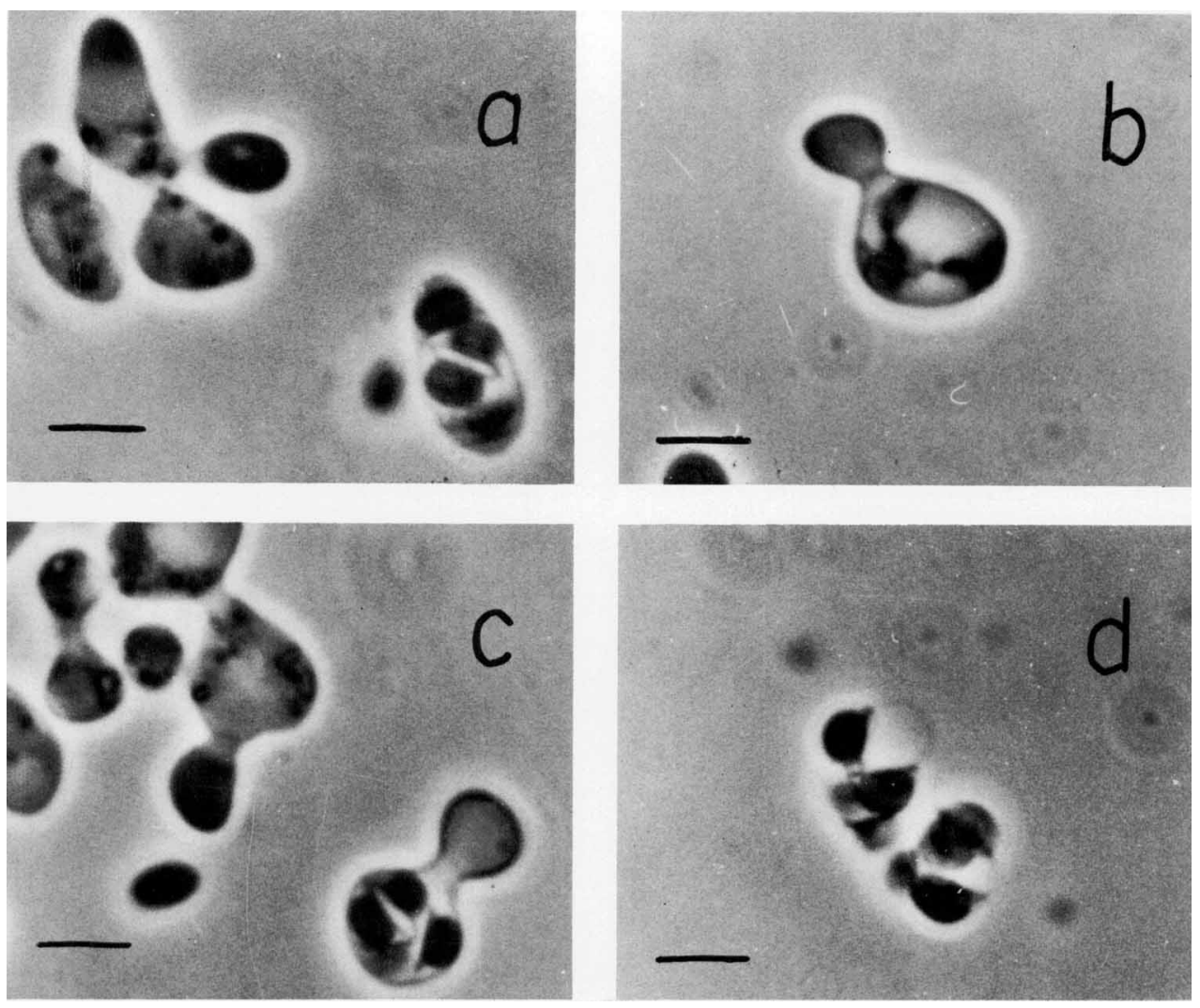

FIG. 1. H. populi sp. nov. strain UCD-FS\&T $68-628 C^{\mathrm{T}}$. After 1 to 2 days at room temperature on malt extract agar, vegetative cells of $H$. populi UCD-FS\&T $68-628 C^{\mathrm{T}}$ undergo conjugation. The zygote has been observed to bud; diploid asci rapidly differentiate ascospores (a). However, the zygote usually differentiates ascospores immediately after conjugation ( $\mathrm{b}$ and $\mathrm{c}$ ). Asci dehisce soon after formation, and clusters of hat-shaped ascospores may be observed within $48 \mathrm{~h}$ (d). Bar $=5 \mu \mathrm{m}$. Other strains of $H$. populi behave very similarly.

Hydrolysis of urea: urease test negative.

Lipolytic activity: negative.

Growth in the presence of 100 or $10 \mu \mathrm{g}$ of cycloheximide per ml: negative. Growth in the presence of $1 \mu \mathrm{g}$ of cycloheximide per $\mathrm{ml}$ : positive (weak).

$\mathrm{G}+\mathrm{C}$ content of the nuclear DNA: 43.8 to 44.2 mol\% (range for five strains [Table 1]).

Type strain. The type strain, UCD-FS\&T 68$628 \mathrm{C}$, was isolated from a slime flux of a cottonwood tree ( $P$. trichocarpa Torrey and Gray) along the Alcan Highway, 55 miles (ca. $90 \mathrm{~km}$ ) northwest of Dawson Creek, British Columbia, Canada. Strain UCD-FS\&T $68-628 \mathrm{C}^{\mathrm{T}}$ has been deposited in the collection of the Yeast Division of the Centraalbureau voor Schimmelcultures in Delft, the Netherlands, as strain CBS 8094 and in the American Type Culture Collection, Rockville, Md., as strain ATCC 48773.

Sources. Table 1 lists the substrates, localities, and $\mathrm{G}+\mathrm{C}$ contents of the nuclear DNAs of the five strains isolated. It appears that $P$. tricho- carpa growing in the northwestern part of North America is the host for $H$. populi.

\section{DISCUSSION}

We have no explanation for the genetic divergence of strain UCD-FS\&T 68-603 compared with the type strain and the other three strains (Tables 2 and 3). Phenotypically, the only differences observed for strain UCD-FS\&T 68-603 compared with the other strains were lack of growth at $30^{\circ} \mathrm{C}$ and latent rather than strong growth on media containing D-xylose and Dmannitol. Allopatry does not appear to play a significant role because the strains were isolated from trees that were growing very large distances from each other in British Columbia and Alaska.

\section{ACKNOWLEDGMENT}

This research was supported by Public Health Service grant GM-16370 from the National Institute of General Medical Sciences to H.J.P. 


\section{LITERATURE CITED}

1. Bernardi, G., M. Faures, G. Piperno, and P. P. Slonimski. 1970. Mitochondrial DNAs from respiratory-sufficient and cytoplasmic respiratory-deficient mutants of yeast. J. Mol. Biol. 48:23-43.

2. Brenner, D. J., G. R. Fanning, A. Rake, and K. E. Johnson. 1969. A batch procedure for thermal elution of DNA from hydroxyapatite. Anal. Biochem. 28:447-459.

3. Britten, R. J., and D. E. Kohne. 1968. Repeated sequences in DNA. Science 161:529-540.

4. Burton, K. 1956. The conditions and mechanism of the diphenylamine reaction for the colorimetric estimation of deoxyribonucleic acid. Biochem. J. 62:315-323.

5. Commerford, S. L. 1971. Iodination of nucleic acids in vitro. Biochemistry 10:1993-1999.

6. Marmur, J. 1961. A procedure for the isolation of DNA from microorganisms. J. Mol. Biol. 3:208-218.

7. Nakase, T., and K. Komagata. 1971. Further investigation on the DNA base composition of the genus Hansenula. J. Gen. Appl. Microbiol. 17:77-84.

8. Phaff, H. J., M. W. Miller, M. Yoneyama, and M. Soneda. 1972. A comparative study of the yeast florae associated with trees on the Japanese Islands and on the west coast of North America, p. 759-774. In G. Terui (ed.), Fermentation technology today. Society of Fermentation Technology, Osaka, Japan.
9. Price, C. W., G. B. Fuson, and H. J. Phaff. 1978. Genome comparison in yeast systematics: delimitation of species within the genera Schwanniomyces, Saccharomyces, Debaryomyces, and Pichia. Microbiol. Rev. 42:161-193.

10. Schildkraut, C. L., J. Marmur, and P. Doty. 1962. Determination of the base composition of deoxyribonucleic acid from its buoyant density in $\mathrm{CsCl}$. J. Mol. Biol. 4:430 433.

11. Scott, D. B., and J. P. van der Walt. 1971. Hansenula dryadoides sp. n., a new species from South African insect sources. Antonie van Leeuwenhoek J. Microbiol. Serol. 37:171-175.

12. Skerman, V. B. D., V. McGowan, and P. H. A. Sneath (ed.). 1980. Approved lists of bacterial names. Int. J. Syst. Bacteriol. 30:225-420.

13. Szybalski, W. 1968. Use of cesium sulfate for equilibrium density gradient centrifugation. Methods Enzymol. 12B: $330-360$

14. van der Walt, J. P. 1970. Criteria and methods used in classification, p. 34-113. In J. Lodder (ed.), The yeasts-a taxonomic study. North-Holland Publishing Co., Amsterdam.

15. Wetmur, J. G., and N. Davidson. 1968. Kinetics of renaturation of DNA. J. Mol. Biol. 31:349-370.

16. Wickerham, L. J. 1970. Hansenula H. et P. Sydow, p. 226-315. In J. Lodder (ed.), The yeasts-a taxonomic study. North-Holland Publishing Co., Amsterdam. 